This PDF is a simplified version of the original article published in Internet Archaeology. Enlarged images, and interactive features which support this publication can be found in the original version online. All links also go to the online version.

Please cite this as: Claßen, E. and Vollmer-König, M. 2021 Roman water pipeline approved for 'adoption' - Public engagement, awareness and benefit from a development-led archaeology project, Internet Archaeology 57. https://doi.org/10.11141/ia.57.2

\title{
Roman Water Pipeline Approved for 'Adoption' - Public engagement, awareness and benefit from a development-led archaeology project
}

\author{
Erich Claßen and Martin Vollmer-König
}

\section{Summary}

The construction of a by-pass in North Rhine-Westphalia resulted in the excavation, recording and relocation of one of the most important archaeological monuments in the Rhineland: a stone and masonry aqueduct up to $95 \mathrm{~km}$ long, which had supplied water to Roman Cologne. As preservation in situ was not possible the pipe was lifted in segments; some were displayed on the site, others were moved to sites nearby. The conservation of the segments was undertaken by apprentices from the Chamber of Crafts and the whole project was a successful collaboration between private, public, business and local communities.

\section{Introduction to the Project}

When a bypass in Hürth-Hermülheim (North Rhine-Westphalia, Germany) was first planned in 2005, it became apparent that the new road would also affect the route of the ancient water pipeline (Eifelwasserleitung), which had supplied Roman Cologne with water from the 1st to the 3rd century AD. Built of solid stone and cast masonry and, at $95 \mathrm{~km}$ long, one of the longest water pipelines in the Roman Empire, it supplied the ancient city with around 20 million litres of drinking water every day. The archaeological legacy of this spectacular structure has been preserved underground for a long time and, as a testament to the Roman settlement landscape and the history of technology, forms one of the most important archaeological monuments in the Rhineland. 
Since the new highway had to be built in a low-lying area in order to pass under a railway line, affecting the water pipeline, it was not possible to keep the monument undisturbed in situ. As part of the approval process for the construction of the new road, it was therefore - according to the legal basis - agreed to examine, document and recover this tribute to ancient engineering. The condition in which the canal would be found was initially unknown.

The archaeological investigation carried out by the private company Archaeonet GbR (Bonn) in 2016 showed that the water pipeline was in good to very good condition. Its Ushaped gutter, built of cast masonry, ran through the entire excavation area. A few metres of the vaulted ceiling and even an inspection shaft had been preserved - an extraordinary stroke of luck (Figure 1).

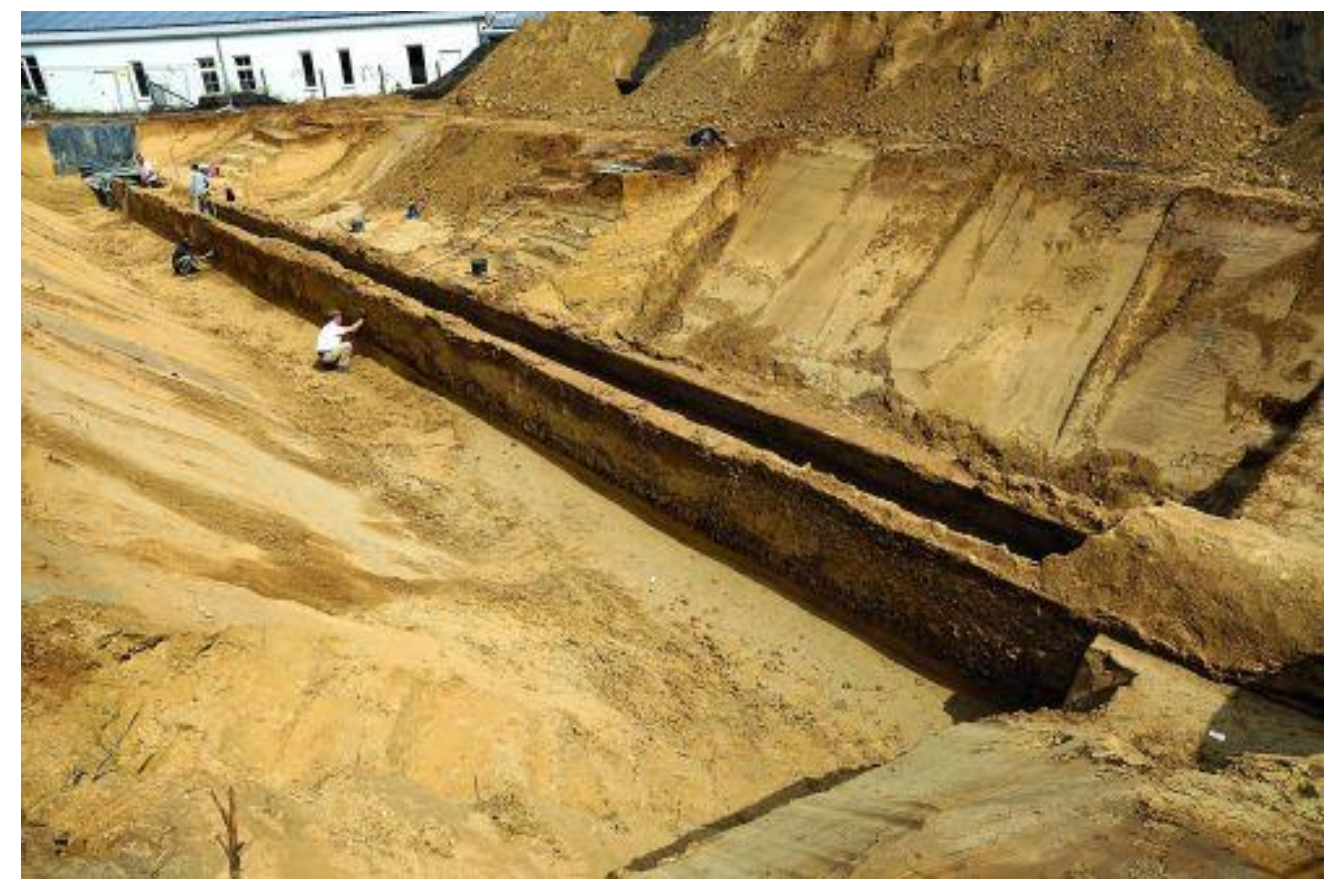

Figure 1: The well-preserved section of the Roman water pipeline near HürthHermülheim during excavation. (A. Thieme/ArchaeoNet GbR) 


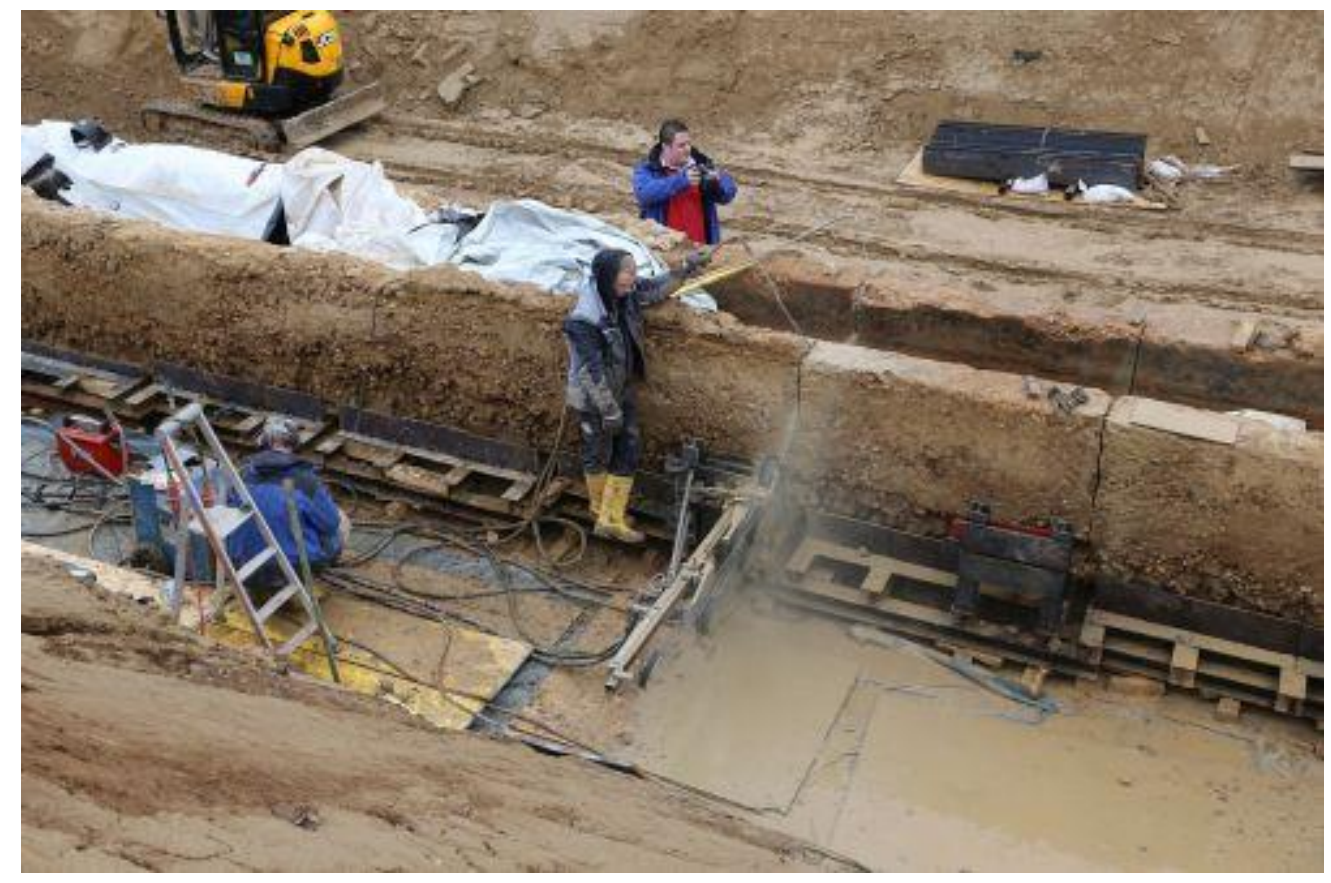

Figure 2: Dividing the Roman water pipeline into manageable sections. (C. Ulbert/ArchaeoNet GbR)

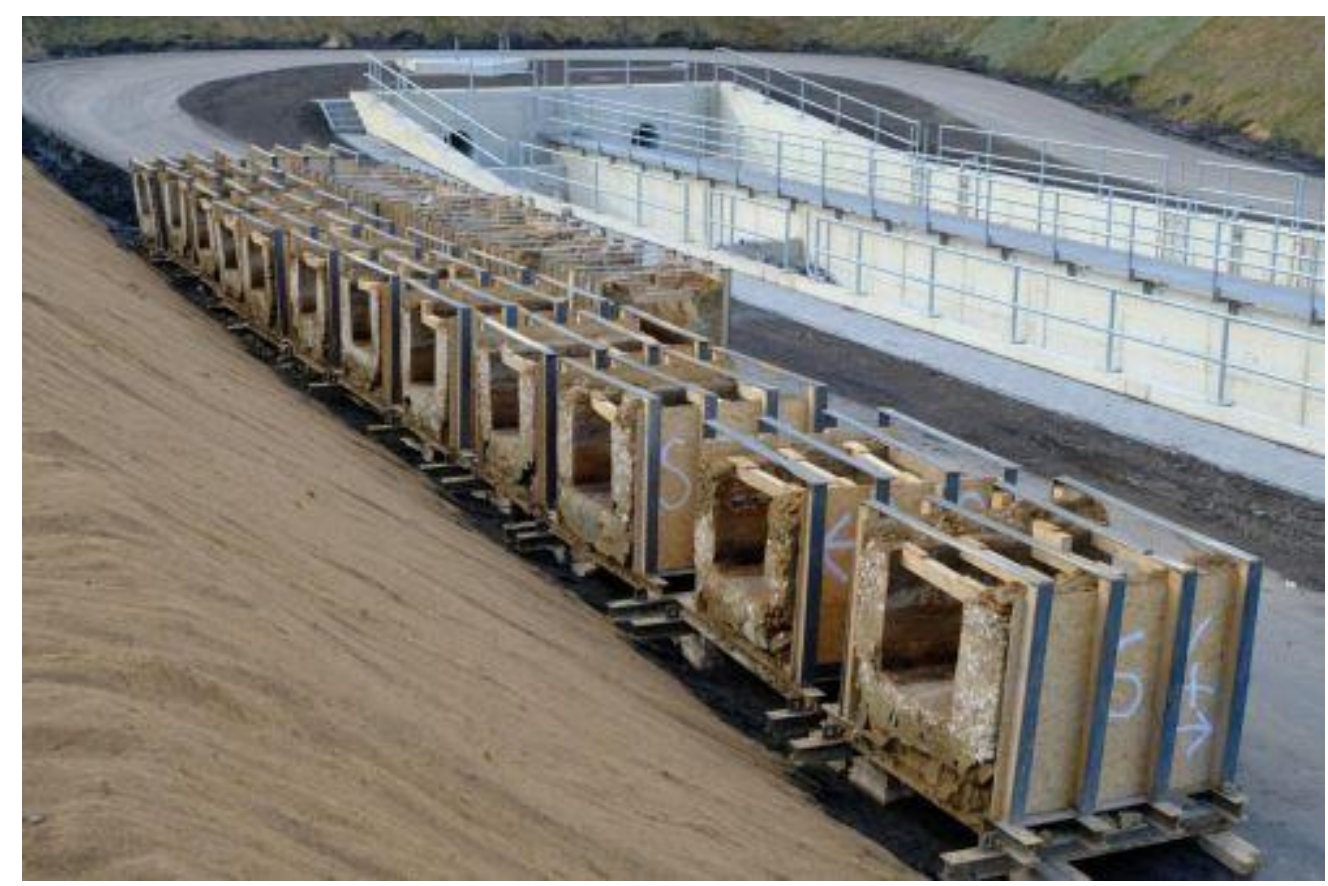

Figure 3: Ready for transportation. (Z. Görür/ArchaeoNet GbR)

After its professional documentation, the water pipeline was recovered piece-by-piece (Figure 2) and temporarily stored (Figure 3). As recompense for their removal to allow the road construction, the LVR - State Service for Archaeological Heritage (LVR-ABR) and the State Office for Roads (Straßen.NRW), agreed to conserve six pieces and to present them to the public on the site. Five of the sections were placed into the embankment on both sides of the new road in summer 2019 to illustrate the original course of the ancient pipe. The sixth piece, with its vault and inspection shaft, is located in the immediate vicinity, on a bicycle and pedestrian bridge that crosses the new street 
(Figure 4). Here, the details of this impressive example of Roman engineering are visible close up.

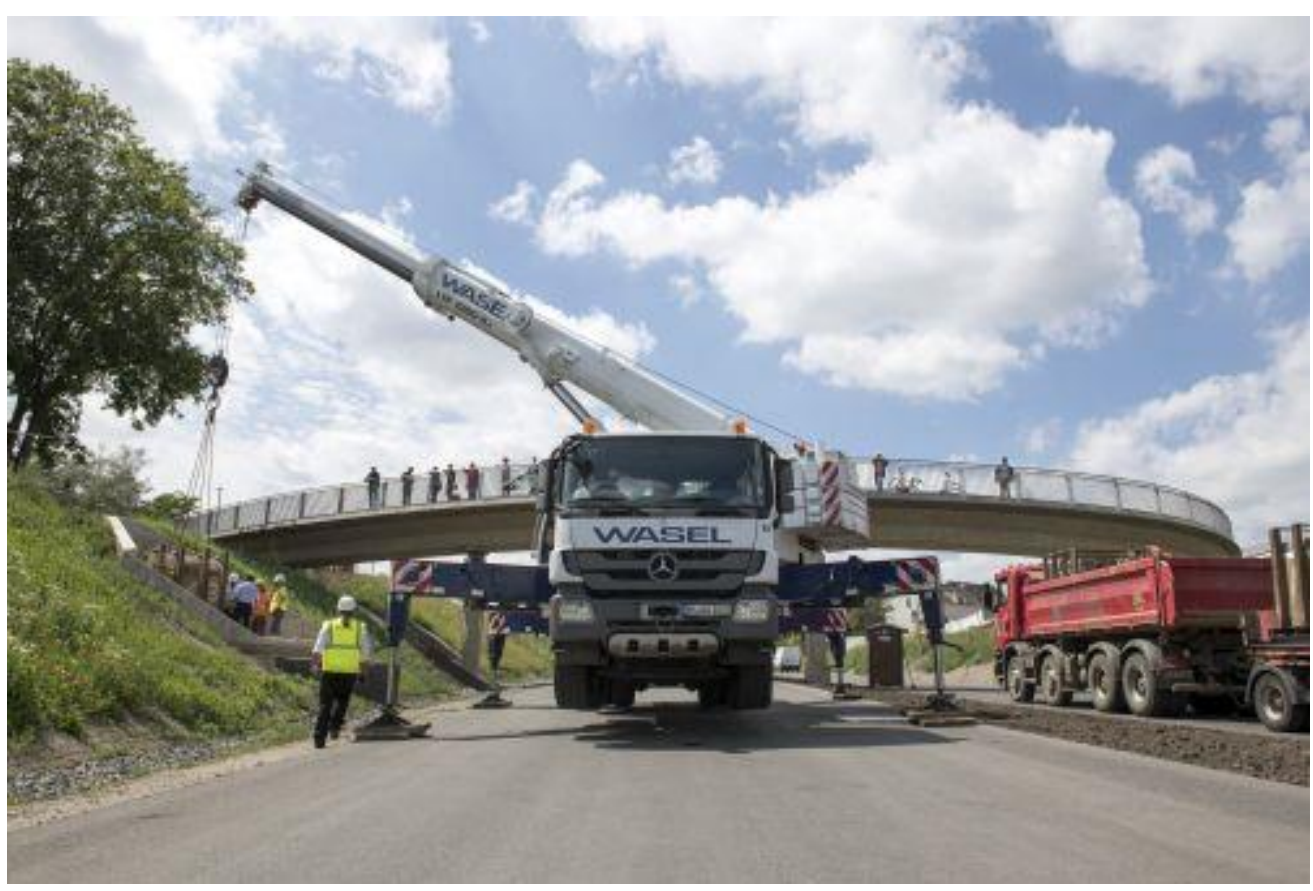

Figure 4: Placing a segment of the Roman water pipeline close to its find spot in the embankment of the new road. (M. Zanjani/LVR-State Service for Archaeological Heritage)

A project was also set up to preserve, restore and present 22 further sections of the ancient water pipeline by offering them to interested parties. The prerequisites for the submission were that those interested had the sections refurbished and that they had to be accessible to the public, accompanied by adequate weather protection and explanatory information boards. In return, the property would be transferred from the state of North Rhine-Westphalia to the customers. There was enormous interest in this unusual offer, which was supported through mediation by an association called Freundeskreis Römerkanal e. V. Municipalities, companies, associations and private individuals who felt connected to the monument as 'neighbours' of the water pipeline or those dealing with the subject of water came forward (Figure 5) and - by summer 2020 - customers have been found for 21 out of 28 pieces. 


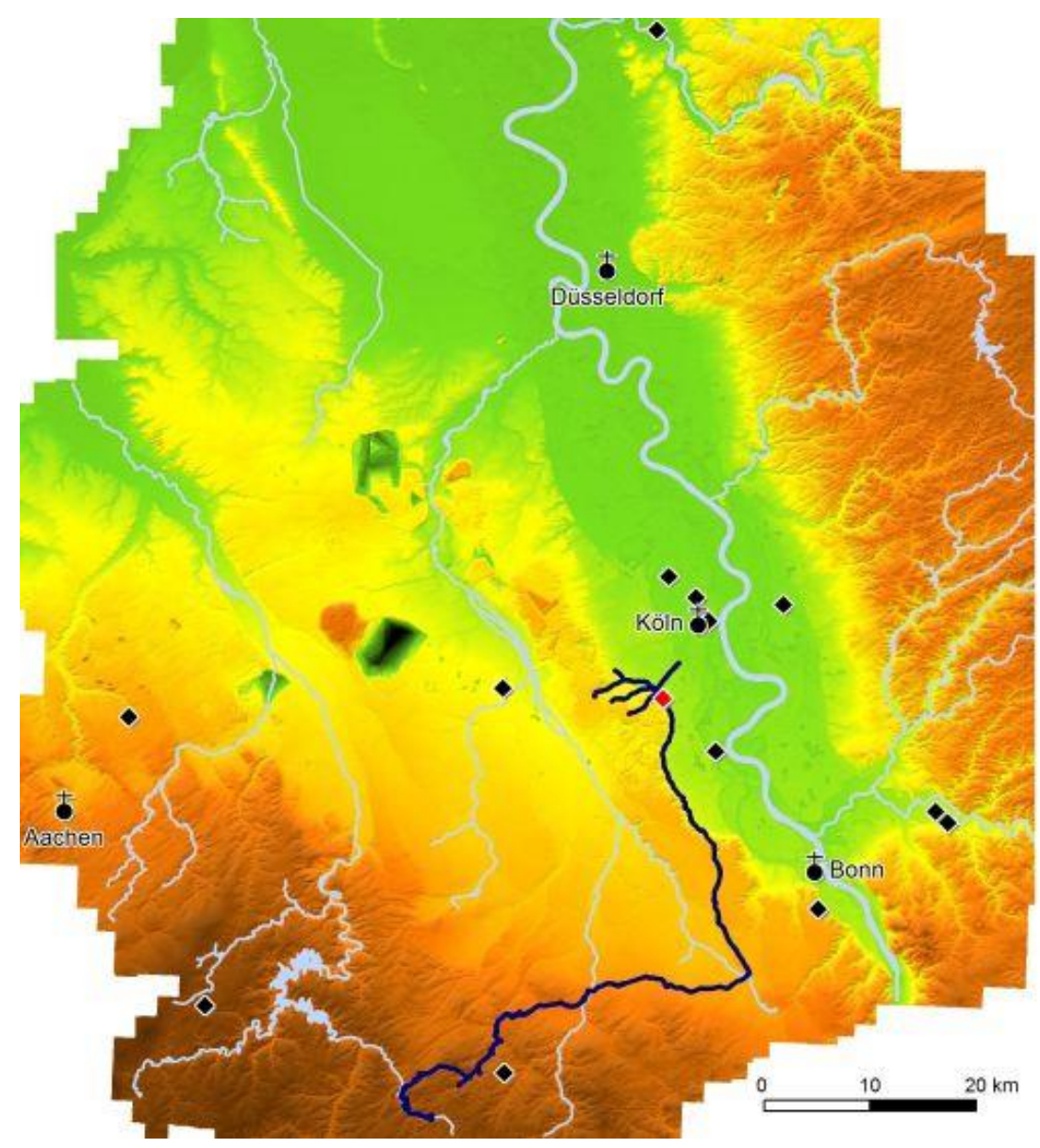

Figure 5: Digital elevation model of the southern part of the Lower Rhine Embayment with major towns and rivers, showing the course of the 'Eifelwasserleitung' (dark blue) and fixed future locations (black) of the sections recovered near Hürth (red). The reinstalled pieces near the excavation site are not plotted neither is one re-installation far from the site, for reasons of scale. (E. Claßen, I. Herzog/LVR-State Service for Archaeological Heritage; base map: (c) Geobasis NRW)

Within the group of interested parties, the STRABAG AG (Cologne), the Chamber of Crafts in Cologne and Peter Schneider Transporte-Baggerbetrieb e. K. (Mechernich) took the initiative to centrally organise the necessary measures for all customers and to bring in considerable contributions of their own. The Chamber of Crafts in Aachen and the Vocational Training Institute of the Construction Industry in North-Rhine Westphalia (BFW) also played a key role in the following process.

In a joint working group of the LVR-ABR, the Cologne district government, the Freundeskreis Römerkanal e. V. and the restorers Stefan Gloßner \& Thomas Sieverding, all aspects of dealing with the recovered parts of the water pipeline were discussed and solutions developed. Questions of logistics, financing, public relations and last, but not least, conservation and reconstruction as well as the installation and presentation of the completed parts had to be clarified.

From their interim storage facility provided by Straßen.NRW, the sections were finally transported to the training centres of the Chamber of Crafts and the BFW for conservation to be carried out under the technical project management of Thomas Sieverding. This ensured the long-term preservation of the sections. In addition to 
specific personal contributions of the two restorers, the work under the direction of the centres' instructors was largely carried out by the apprentices, who tackled the task with enthusiasm and quality - ancient artisanship meets modern young people (Figure 6).

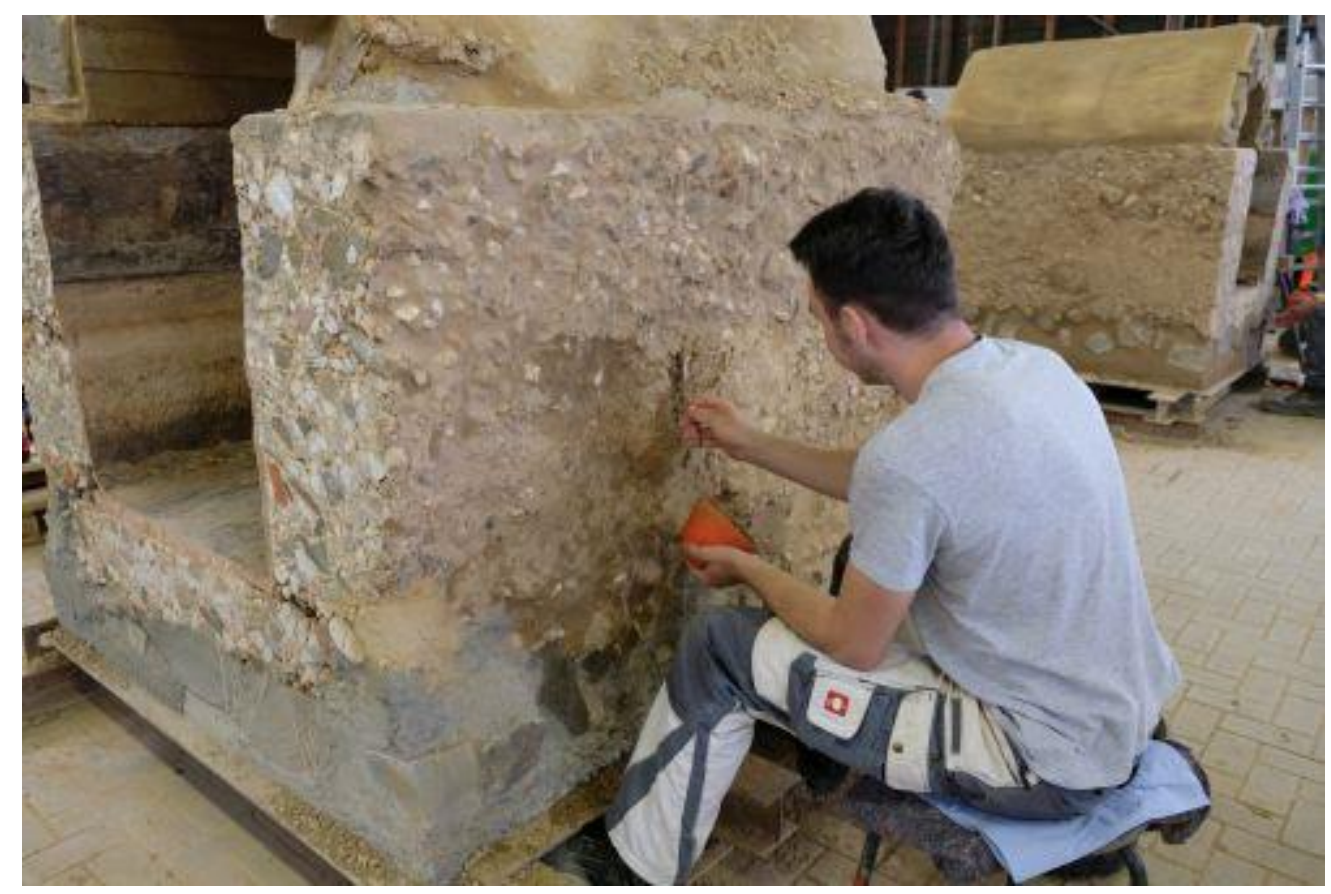

Figure 6: Trainee from the Cologne Chamber of Crafts during the restoration of a segment of the water pipeline. (Th. Sieverding)

The vaults were in all cases reconstructed in order to ensure the stability of the gutters and to give the monuments their typical 'look', which often appears as a distinguishing feature of this Roman construction in its course from the Eifel to Cologne. After their completion, the parts of the Roman water pipeline are being gradually handed over to their new owners and transported to their final destinations (Figure 7). Together with the restored original monument, they receive not only the title deed, but also individual documentation that includes all stages of the archaeological investigation, recovery and conservation of their almost 2000-year-old protégés in text, image and film. The final task is to place the monuments on site in such a way that they will be protected against damage in the future and will help to bring the Roman past closer to citizens and visitors. The variety of aspects under which this will take place, depending on the perspective of the new monument owner, is just as remarkable as the overall project itself. 


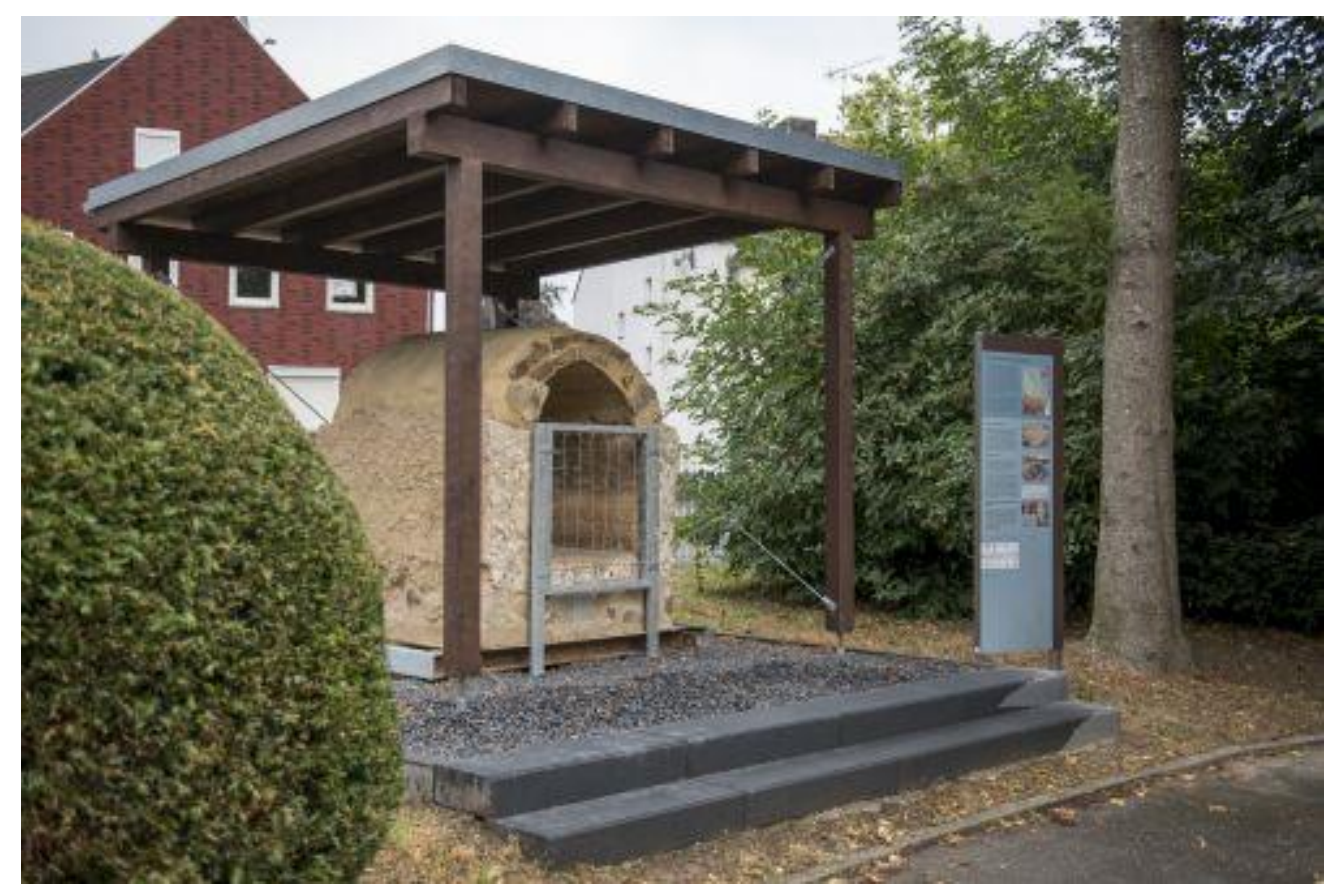

Figure 7: Final re-installation of a section of the Roman water pipeline with canopy and information panel at the Heilig-Geist-Gymnasium in Würselen. (M. Zanjani/LVR-State Service for Archaeological Heritage)

Such an enthusiastic and constructive interaction between communities, companies, associations, authorities and private individuals, with the aim of preserving a significant cultural monument for the public, contributes to raising awareness of the importance of the archaeological heritage and goes far beyond this individual case.

\section{Acknowledgements}

We thank all project partners for their outstanding commitment and all those who have agreed to take care of the conservation, preservation and permanent presentation of a section. In addition, we are grateful to Anneli Wanger-O'Neill (Munich) for proof-reading this text.

\section{Bibliography}

Grewe, K. 1986 Atlas der römischen Wasserleitungen nach Köln, Rheinische Ausgrabungen 26. Köln.

Kunze, F. 2017 'Scheibchenweise Römerkanal - Bergung des Bodendenkmals in Hermülheim', Archäologie im Rheinland 2016 (Darmstadt), 161-63.

Vollmer-König, M. 2019 'Zur "Adoption" freigegeben: die römische Eifelwasserleitung von Hürth-Hermülheim', Archäologie im Rheinland 2018 (Oppenheim), 230-33. 